\title{
The white-topped pitcher plant-a case of precarious abundance
}

\author{
George W. Folkerts
}

White-topped pitcher plants, among the most attractive members of the genus Sarracenia, are in great demand for floral displays, in the USA and Europe. It is doubtful whether current levels of exploitation are sustainable; there is no way of controlling harvesting for the domestic market and the monitoring of exports is difficult. As well as this pressure, wild populations are perhaps in even greater danger from changes in land use.

\section{Introduction}

On the coastal plain of south-eastern North America, from south-eastern Virginia south to central Florida and west to east-central Texas, there are habitats that support one of the most remarkable assemblages of plants in the world. Their unique nature partly derives from an unusually high diversity of carnivorous plants. The bog sites where these assemblages are found differ somewhat ecologically, but share a number of features, including wet, acid soils, frequent fires (at least under the primeval fire regime), and often a low availability of soil nutrients. Presumably these features have promoted the evolution of a number of unique carnivorous genera, including the Venus flytrap Dioneae muscipula and the North American pitcher plants of the genus Sarracenia. Additionally, although the genera have not evolved here and are not endemic, a number of species of butterworts Pinguicula spp., bladderworts Utricularia spp., and sundews Drosera spp., are present. Several species in these genera are restricted to bogs in southeastern USA.

\section{Pitcher plants}

Among the most conspicuous plants in the bogs are the species of Sarracenia, causing the sites to often be called pitcher plant bogs. Depending on taxonomic opinion, as many as
11 species may be distinguished. There are at least eight very distinctive types (McDaniel, 1971). Two pitcher plants with very restricted ranges, the green pitcher plant $S$. oreophila and the Alabama canebrake pitcher plant $S$. rubra alabamensis, have long been known to be declining (Folkerts, 1977) and are currently protected by US law. The white-topped pitcher plant $S$. leucophylla, considered by many to be the most beautiful, is used here to exemplify the problems that many of the organisms of these habitats are encountering. The leaves of this plant are tubular, up to $90 \mathrm{~cm}$ in height, and taper to a narrow base. The top portion of the leaf and the hood, which overhangs the orifice, are mainly bright white, the areas between the veins lacking chlorophyll. Evolutionarily, this plant seems to have sacrificed photosynthesis in the upper portion of the leaf, creating the white, flower-like appearance, which is very effective in attracting insects from which the plant obtains vital nutrients. The species ranges from south-eastern Georgia through the Florida Panhandle and southern Alabama to south-eastern Mississippi.

\section{The role of fire in maintaining pitcher plant bogs}

Pitcher plant habitats along the Gulf Coast of south-eastern North America have been dis- 
appearing rapidly in the last several decades (Folkerts, 1982). Although large stands of the white-topped pitcher plant were once common, populations are now smaller and much less abundant than they were 30 years ago. Many factors are involved. One major factor relates to fire. There is abundant evidence that many of the plant communities on the coastal plain of south-eastern North America were historically maintained by natural fires (Komarek, 1974). Writings of early American naturalists attest to this fact (Brickell, 1737; Bartram, 1791). Before the American Indians arrived from Asia, fire in these ecosystems was started by lightning. In pre-Columbian times, fire generated by a single strike could have spread for dozens, perhaps hundreds, of kilometres, even though the burn was probably patchy. The only barriers to the spread of fire would have been watercourses, relatively infrequent rocky areas, the presence of communities in which natural processes did not generate sufficient fuel to carry fire, and areas where litter consisted largely of materials that did not ignite readily or were slow to burn.

The white-topped pitcher plant and almost every other species of plant that shares its habitat are perennial herbaceous species in which the perennating portions (generally rhizomes, bulbs or corms) lie beneath the soil surface and therefore are not harmed by fires. Fire destroys only the aerial portions and in most species these regenerate in a few months or by the next season. It is this adaptation to fire that may play a major part in spelling the demise of the white-topped pitcher plant and many associated plants and animals. From the 1930 s until recently, fire was viewed as a catastrophe that should be prevented at all costs. The public education programme, initiated by the US Forest Service and involving wellknown symbols such as 'Smokey the Bear' succeeded in convincing the biologically naive public that fire was an unnatural event to be feared. This campaign has had some drastic detrimental ramifications. A prime example exists in the massive public and bureaucratic outcry that resulted from the 1988 fires in Yellowstone National Park in the western United States. The scientific evidence demon-

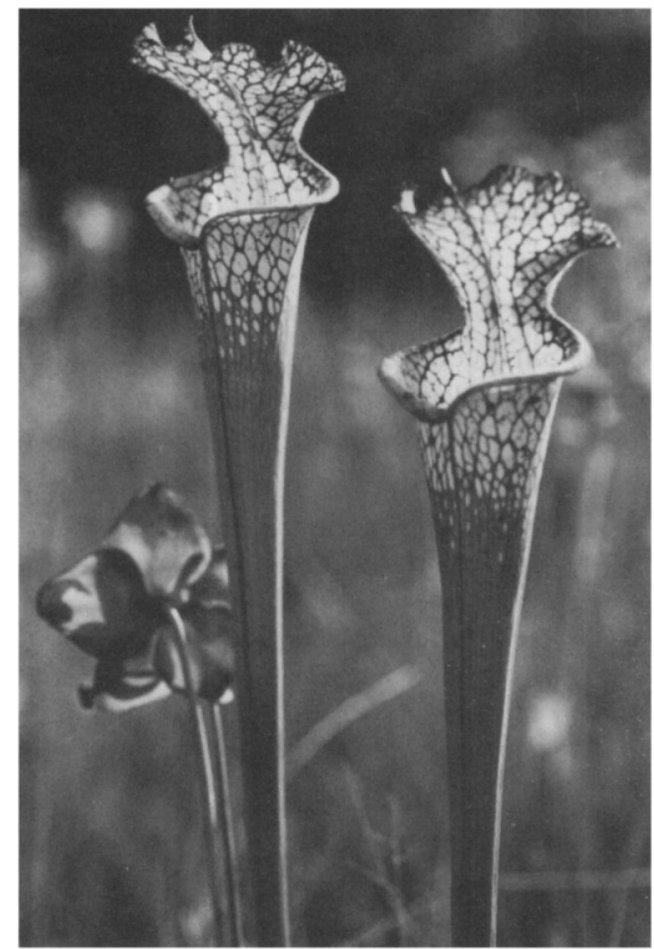

Insect-trapping leaves of the white-topped pitcher plant Sarracenia leucophylla. On the lower left is a mature fruit (George Folkerts).

strated that the Yellowstone ecosystem was not only harmed very little, but may have benefited significantly (Boyce, 1989). In any event, fire control and suppression was an accepted practice and still is in many quarters. Only in the last decade has this view begun to change.

Without frequent fire, the pitcher plant community rapidly disappears as a result of ecological succession. Invasion by fire-intolerant vines, shrubs and trees, whose propagules are dispersed by wind or birds occurs almost immediately. As the woody species mature, shading begins to affect the bog plants detrimentally, almost all of which are adapted to conditions in full sun. Drying of the bog soil occurs as a result of transpiration of large amounts of water through the woody plants. After a period of from 3-5 years without fire, the accumulated litter is sufficiently deep to prevent sexual reproduction in the pitcher plants, which seem to require areas of bare mineral soil for seed germination and seedling 
growth. This failure in seedling recruitment is aggravated by the fact that stress resulting from the presence of competing woody species causes the pitcher plants to produce fewer flowers. Eventually the great majority of pitcher plants in a stand may fail to flower. However, the rhizomes of the white-topped pitcher plant are very long-lived and seem able to survive for decades in a dormant state without producing flowers or pitchers, although inconspicuous phyllodia may be produced. Evidence for this comes from examination of pitcher plant sites planted to pines in the early 1960s. During the 1970s and early 1980s there was no sign of the plants, yet after the pines were harvested in the late 1980s, active plants of $S$. leucophylla and $S$. flava with large rhizomes were present. It appears that if competing, shading vegetation is removed by fire or clearance, dormant rhizomes again produce above-ground parts. The maximum length of time that the rhizomes can survive in dormancy is not known.
The ability of the white-topped pitcher plant to continue to produce visible vegetative parts without reproducing sexually, has resulted in a dilemma for conservationists concerned about its future. There are approximately 250 known sites at which the species still occurs. Many of these are along public roads, and a number are well known to local people. In cases where the public perceives a species as relatively abundant, conservation groups and US resource agencies have justifiably been reluctant to propose the plant for formal protection lest they be accused of 'crying wolf'. Nevertheless, most of the populations of the white-topped pitcher plant are functionally extinct because they are not reproducing.

It might seem that the solution is obvious: merely initiate a programme of burning, which would eliminate competing vegetation and restore the successional stage that is conducive to pitcher plant population health. There are, however, a number of significant

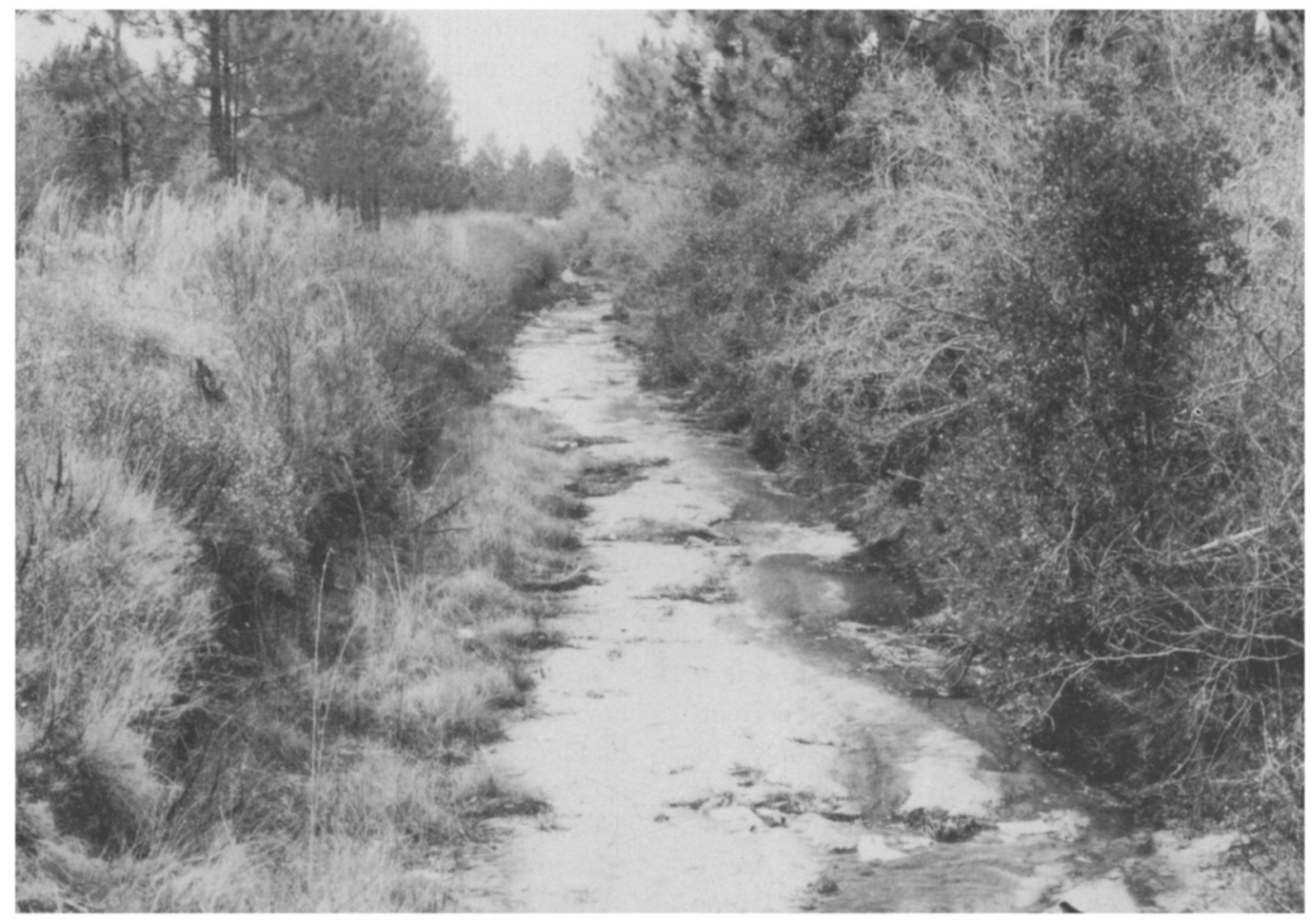

A large drainage ditch in the eastern Florida Panhandle constructed to dry out bog soils to enable the planting of pine trees (George Folkerts). 
problems associated with this seemingly simple answer. First, natural fires no longer spread even if they are allowed to burn. Roads, railways, canals, drainage ditches, developed areas and constructed fire breaks all prevent the spreading of fires. Secondly, problems with smoke and possible spread of fire into residential areas, agricultural fields and managed forests make controlled burning difficult and make burning permits difficult to obtain. Thirdly, prescribed burning, when it is done by public or private land management agencies, is traditionally done in the winter. Winter burning will not successfully remove competing woody species from pitcher plant habitats unless the site is burned every year for a number of years. Circumstantial evidence obtained from lightning strike and thunderstorm records indicates that 'natural' burns probably occurred most frequently in the spring and summer.

\section{The effect of land-use changes}

If lack of burning were the only problem, the future of pitcher plant communities would be bleak. But several other degrading factors are acting to exacerbate the situation. Intensive monoculture of pines has become a major land use activity in the range of the whitetopped pitcher plant in the past 30 years. Pitcher plant habitats are too wet for economic growth of commercial pine species. The timber and pulp industry view bogs as sites to be drained and converted to profit. In a sense, the industries can hardly be blamed. They would contend that they pay taxes on the land and have been given no economic incentives to protect any components of the natural world. To their credit, a few corporations have attempted to protect natural communities when the economic sacrifice was not too great.

Conversion of bogs to even-aged stands of pine involves drainage, which cause irreversible changes in habitat. In addition to soil drying, the closely spaced pines cast heavy shade. Eventually a thick layer of shed pine needles accumulates, killing any seedlings or small plants present. Site preparation involv- ing discing and chopping of the soil may kill most of the pitcher plants before the pines are planted. Herbicides are often applied to control competing hardwoods and these may eliminate the few remaining living pitcher plants. Under these conditions, prospects for restoration of a pitcher plant community are poor.

\section{The trade in pitchers}

A third major threat to the white-topped pitcher plant has intensified in the last five years. Because of their beauty, pitchers of this species have been cut for use in floral displays. Until recently, the trade in pitchers was limited and only a few sites were regularly harvested. However, since 1984 pitcher harvest has increased. In 1988 the Office of Scientific Authority of the US Fish and Wildlife Service received applications for permits to harvest over three million pitchers of the white-topped pitcher plant. It is doubtful that this many pitchers are present in all existing populations. The Office of Scientific Authority approved the export of approximately half a million pitchers on the basis of its legal authority resulting from agreements under the Convention on International Trade in Endangered Species of Wild Fauna and Flora (CITES) (the white-topped pitcher plant is listed in Appendix II of CITES). However, there is currently no method by which pitcher harvest for the domestic market can be controlled. In fact it is very difficult even to monitor export to determine if permit holders are complying with prescribed limits. The bulk of the exported pitchers end up in floral displays in the UK, the Federal Republic of Germany, the Netherlands and Scandinavian countries.

It seems almost certain that a twice-yearly harvest (the plant produces two crops of pitchers during a season) of large numbers of pitchers from a population is detrimental to this plant. The pitchers are photosynthetic structures as well as the means by which the plant attracts and digests insect food. Harvest is also causing physical damage to the habitat as a result of vehicle and human traffic. Even 


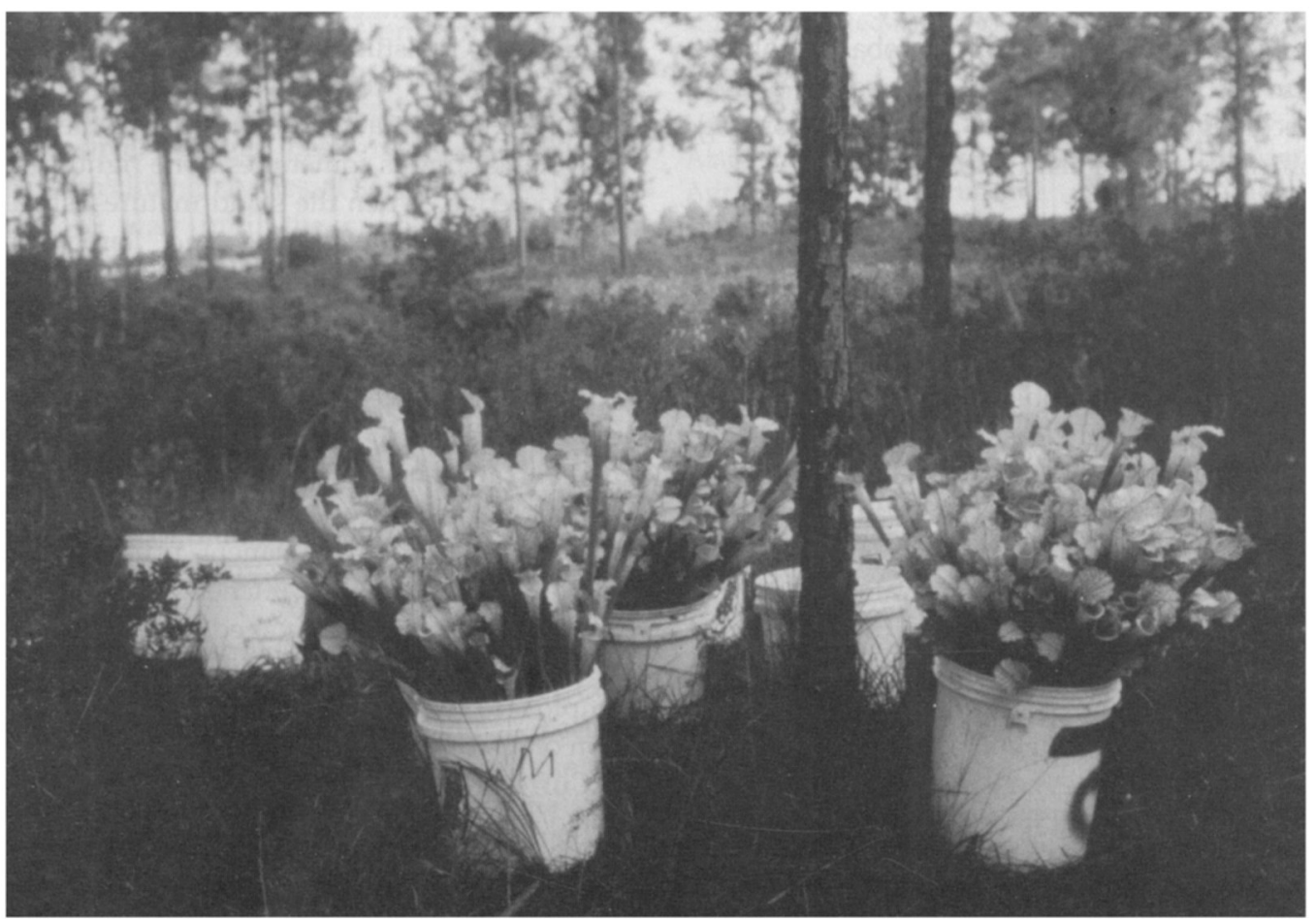

Harvested pitchers ready to be transported to cold storage for eventual sale in the florist trade (Mark Bailey).

though most would agree that the practice is damaging, long-term studies that support this view have not been done. Even if they were undertaken now many sites might be damaged irreparably before the results were available. Harvesters have not been required to show that their activities are not damaging.

\section{Other damaging factors}

Damage to white-topped pitcher plant populations resulting from fire suppression, forest practices and pitcher harvest must be viewed as catastrophic. Even so, many other degrading processes and damaging practices are also occurring. Pitcher plant bogs appear to be lush. Landowners who do not realize that plants growing in areas with low nutrients do not make good forage have attempted to turn bogs into pastures. Although cattle do not eat the pitchers, they do eat the flowers. After a few years of grazing, trampling by livestock eliminates most of the pitcher plants. Soil compaction may inhibit recovery if grazing pressure is reduced. Pond construction has destroyed a large number of bogs on slopes, which depend on seepage for moisture. Herbicide spraying, urbanization, canal and road construction, off-road vehicle traffic and mowing are all taking their toll.

A final factor that is affecting survival of the white-topped pitcher plant and many other bog species, especially the carnivorous kinds, is the digging of living plants for sale or trade by commercial operators and the growing number of carnivorous plant fanciers. These groups often profess a conservation ethic, but experience indicates that many enthusiasts cannot resist having one more plant of a slightly different type for their greenhouse or artificial bog. As a result, populations of extremely rare and legally protected species have been decimated. A common but unpersuasive excuse offered by the diggers is that they are rescuing plants that probably would 
have been destroyed anyway. The whitetopped pitcher plant can probably tolerate current levels of removal, but as the species becomes rarer, each plant will be of more significance and demand will increase.

\section{The need for protection}

One might assume that stands of white-topped pitcher plants on public lands are safe, but the reverse is often the case. Populations exists in two national forests, several military bases and a number of state forests, parks and other public properties. National forest populations are protected only by administrative initiative, since the plant has no legal protection. Those that are offered some protection are often improperly managed, at times as a result of insufficient knowledge about the needs of the community. Ditches constructed to control prescribed burns result in soil drying. Buffer areas to maintain openness and protect the source of the bog moisture are seldom maintained. Clear-cutting, a common practice on many managed public lands, often disturbs the bog soil. Replanting is sometimes done right up to the bog edge. When the stand matures, shading and needlefall become problems. Additionally, dense stands of trees planted upslope from bogs may remove much of the available soil moisture before it can reach the bog. Unfortunately, policies on many of the public lands in the US are dictated more by bureaucratic inertia, industry pressure and political expedience than by wise and farsighted resource management principles. In the few cases in which pitcher plant habitats have been properly managed, it has been at the initiative of a few knowledgeable agency employees who did so in the face of opposition or apathy.

Currently the white-topped pitcher plant is listed in at least some category of endanger-

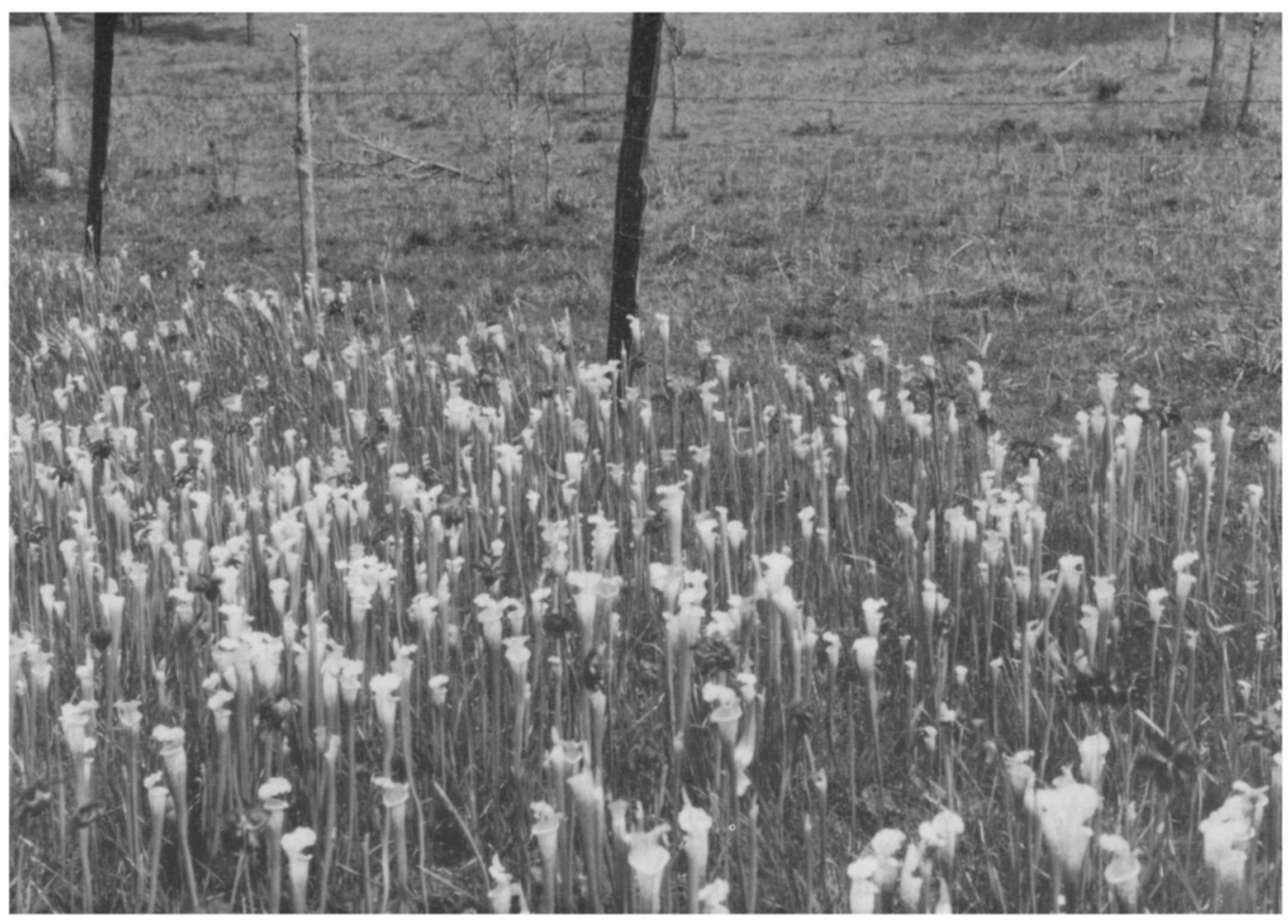

The area behind the fence has been grazed for two years. Before grazing it resembled the foreground area, which has never been grazed. Grazing rapidly eliminates nearly all of the bog flora (George Folkerts). 
ment or rarity by agencies in all the states in its range. This reflects its precarious status, but the lists are seldom backed by legal protection. If they are, enforcement is difficult or impossible. As has been the case with so many declining species, it seems that we may have to wait until the species reaches the point when it qualifies for protection under federal law. Then we can fight a last ditch battle and hope that a few remnants can be saved. It is ironic that agencies, industries and groups who strongly object to legal protection for endangered species, because it may interfere with their traditional endeavours or with profit, are continually in the process of pushing species to the point where legal protection is necessary.

Sarracenia leucophylla is not the only species inhabiting the bogs of the south-eastern US. These sites harbour more than 20 other species of carnivorous plants, making them some of the most diverse carnivorous plant habitats in the world. Many other rare and declining species are present, including the Panhandle lily Lilium iridollae, the yellow fringeless orchid Platanthera integra, and the bog spicebush Lindera subcoriacea. Over 12 species of insect are obligate associates of pitcher plants (Rymal and Folkerts, 1982). The bogs are habitat for crayfishes Fallicambarus spp., a number of which have not yet been scientifically described. All of these species will share in the white-topped pitcher plant's fate. At present there is little cause for optimism.

\section{Acknowledgments}

Bruce MacBryde kindly supplied some of the information included here. Debbie Rymal Folkerts, Nick Holler, Dan Speake and Lee Stribling read and criticized the manuscript. Mark Bailey generously allowed the use of a photograph. A portion of the information in this article was obtained during a study supported by the US Fish and Wildlife Service contract 14-16-0009-1550-RWO-14 through the Alabama Cooperative Fish and Wildlife Research Unit (Co-operators: US Fish and Wildlife Service, Alabama Division of Game and Fish, Alabama Agricultural Experiment Station, Auburn University, and Wildlife Management Institute).

\section{References}

Bartram, W. 1791. Travels through North and South Carolina, Georgia, East and West Florida. Philadelphia.

Brickell, J. 1737. Natural history of North Carolina. Published by the author, Dublin, Ireland.

Boyce, M.S. 1989. Effects of the 1988 fires on ungulates in Yellowstone National Park. Proceedings of the 17th Tall Timbers Fire Ecology Conference. Tall Timbers Research Station, Tallahassee, Fla. (in press).

Folkerts, G.W. 1977. Endangered and threatened carnivorous plants of North America. In Extinction is For Ever: The Status of Threatened and Endangered Plants of the Americas (eds G. T. Prance and T. S. Elias), pp. 301-313. The New York Botanical Garden, Bronx, New York.

Folkerts, G.W. 1982. The Gulf Coast pitcher plant bogs. Amer. Scient. 70, 260-267.

Komarek, E.V. 1974. Effects of fire on temperate forests and related ecosystems: southeastern United Sates. In Fire and Ecosystems (eds T. T. Kozlowski and C. E. Ahlgren), pp. 251-277. Academic Press, New York.

McDaniel, S. 1971. The genus Sarracenia (Sarraceniaceae). Bull. Tall Timbers Res. Sta. 9, 1-36. Rymal, D.E. and Folkerts, G.W. 1982. Insects associated with pitcher plants (Sarracenia: Sarraceniaceae) and their relationship to pitcher plant conservation: a review. J. Ala. Acad. Sci. 53, 131-151.

George W. Folkerts, Department of Zoology and Wildlife Science, Alabama Cooperative Fish and Wildlife Research Unit, and Alabama Agricultural Experiment Station, Auburn University, Auburn, Alabama 36849-5414, USA. 